\title{
Prevalence of joint hypermobility in children with inguinal hernia
}

\author{
Reza Shiari, Shima Salehi, Mehrnoush Hassas Yeganeh, Vadood Javadi Parvaneh \\ From 21st European Pediatric Rheumatology (PReS) Congress \\ Belgrade, Serbia. 17-21 September 2014
}

\section{Introduction}

The Joint Hypermobility Syndrome (JHS) is a multi-system inherited connective tissue disorder caused by defective fibrous tissue matrix proteins such as collagen. Joint hypermobility has been occurred more frequently in children, with diminishing occurrence as age increases in population studies. The prevalence of hypermobility in children has been reported to be between 2.3 and $30 \%$. Hypermobility is associated with weakness of abdominal wall and pelvic floor and predisposes to increased risk of hernia, hiatus hernia, and rectal prolaps.

\section{Objectives}

The aim of this study is to determine the relation between of joint hypermobility syndrome (JHS) and unilateral and/ or bilateral inguinal hernia in children.

\section{Methods}

A Case-control study has been conducted in which 67 patients with inguinal hernia (unilateral and/or bilateral) accompanied by 86 healthy control group (age between 4 to 16 years old). The joint hypermobility was assessed by searching in all of the possible joints according to Beighton scoring system. Student's $t$-test and Chi-squared test were used for the test of significance where applicable and $P<0.05$ was considered significant.

\section{Results}

The prevalence of joint hypermobility in children with inguinal hernia (unilateral and/or bilateral) was $80.6 \%$ (54 of 67 ). The 60 out of 67 patients $(89 \%)$ had unilateral and $1(10.4 \%)$ cases had bilateral hernia.The prevalence of joint hypermobility in the group with unilateral hernia was $80 \%$ (48 of 60 ) and in bilateral hernia was $14.3 \%$ ( 1 of 7 ). Comparison of the prevalence of disease

\footnotetext{
Pediatric Rheumatology, Shahid Beheshti University Of Medical Sciences,
} Tehran, Iran, Islamic Republic Of and take full advantage of:

- Convenient online submission

- Thorough peer review

- No space constraints or color figure charges

- Immediate publication on acceptance

- Inclusion in PubMed, CAS, Scopus and Google Scholar

- Research which is freely available for redistribution 